89. Howarth $\mathbf{C l}$, Ellis $\mathrm{K}$. The relative intelligibility threshold for one's own name compared with other names. O J Exp Psychol 1961;13:236-9.

90. Oswald I, Taylor A, Treisman M. Discrimination responses to simulation during human sleep. Brain 1960:83:440-53.

91. Snyder CR, Fromkin HL. Uniqueness: The Human Pursuit of Difference. New York: Plenum Press, 1980.

92. Dion KL. Names, identity, and self. Names 1983;31:245-57.

93. Nuttin JM Jr. Narcissism beyond Gestalt and awareness: the name letter effect. Eur J Soc Psycho 1985:15:353-61.

94. Hoorens $\mathbf{V}$, Todorova $\mathrm{E}$. The name letter effect: attachment to self or primacy of own name writing? Eur J Soc Psychol 1988;18:365-8.

95. Schachter M. Paroxystic auto-prosopagnosia and epilepsy. Physio-pathological correlation or chance association? Schweiz Arch Neurol Neurochir Psychiatr 1976;119:167-76.

96. Simpson SJ, Hines PJ. Self-discrimination, a life and death issue. Science 2002;296:297.

97. Plato. The Republic. (English translation by B Jowett). Oxford: Oxford University Press, 1892.

98. Harvey G. Animism: Respecting the Living World. New York: Columbia University Press, 2006.

99. Chang SC. The self: a nodal issue in culture and psyche-an Eastern perspective. Am J Psychother 1982;36:67-81.
100. Mead GH, Morris CW. Mind self and society from the standpoint of a socia behaviorist. Chicago: University of Chicago Press, 1934

101. Lévinas E. Emmanuel Lévinas: basic philosophical writings. In: Peperzak AT Critchley S, Bernasconi R, eds. Bloomington: Indiana University Press, 1996.

102. Lévinas E. The Lévinas reader. In: Hand S, ed. Oxford: Blackwell Publishers, 1989

103. Lévinas E. Totality and Infinity: An Essay on Exteriority. Dordrecht: Kluwer Academic Publishers, 1991.

104. Aristotle. On the Parts of Animals. (English translation by W Ogle). Oxford Editions, Oxford, 1912.

105. Reiss TJ. Mirages of the Selfe: Patterns of Personhood in Ancient and Early Modern Europe. Stanford, CA: Stanford University Press, 2003.

106. Atkinson JR. The Mystical in Wittgenstein's Early Writings. New York: Routledge/ Taylor \& Francis, 2009

107. Schopenhauer A. The World as Will and Representation. Vol I (Translated by EFJ Paynes, first published in 1958 by The Falcon Wing's Press). Mineola, NY: Dover Publications, 1966.

108. Noë A. Out of Our Heads: Why You Are Not Your Brain, and Other Lessons from the Biology of Consciousness. New York: Hill \& Wang / Farrar Straus \& Giroux, 2009.

109. Saukko P. Studying the self: from the subjective and the social to personal and political dialogues. Qual Res 2002:2:244-63.

110. Chalmers DJ. The Conscious Mind: In Search of a Fundamental Theory. Oxford: Oxford University Press, 1996.

\title{
Poem
}

\section{Eat more fatty fish}

and exercise more.

this is what I advise my patients

when their good cholesterol is low

triglycerides high.

I use a letter

a thin piece of paper light on words which makes for quite a lean envelope mostly bones really.

most patients swim past.

and yet a few always take the bait ending up in front of crumbled ice and prices per pound.

dressed in workout clothes

they ask the man in the plastic smock

for a pound of fatty fish-salmon

a piece freshly caught.

\section{Adam Possner}

Correspondence to Assistant Professor Adam Possner, General Internal Medicine, George Washington University, Medical Faculty Associates, 2150 Pennsylvania Ave NW, Suite 2-105 South, Washington, DC 20037, USA; apossner@mfa.gwu.edu

Competing interests None.

Provenance and peer review Not commissioned; not externally peer reviewed.

Published Online First 16 February 2011

Med Humanit 2011;37:122. doi:10.1136/jmh.2011.007047 